\title{
Evaluation of the effects of microscale chemical and isotopic heterogeneity of coral skeleton on conventional $\mathrm{Sr} / \mathrm{Ca}$ and $\delta^{18} \mathrm{O}$ paleothermometers
}

\author{
TAkehiro Mitsuguchi \\ Institute for Carbonate Geochemistry, 5-5 Ninomiya-cho, Chuo-ku, Kobe 651-0093, Japan. \\ e-mail: aa153740@nyc.odn.ne.jp
}

Recent studies using secondary ion mass spectrometry revealed microscale heterogeneity of Sr/Ca and $\delta^{18} \mathrm{O}$ in shallow-water coral skeletons, i.e., $\mathrm{Sr} / \mathrm{Ca}$ and $\delta^{18} \mathrm{O}$ differ significantly between two basic microfeatures of the skeleton: the center of calcification (COC) and surrounding fibrous skeleton (SFS). The COC, in contrast with the SFS, consists of highly irregular crystals intermingled with significant amount of organic matter; therefore, analyzing the SFS only would probably be favourable for paleotemperature reconstruction. Conventional $\mathrm{Sr} / \mathrm{Ca}$ and $\delta^{18} \mathrm{O}$ paleothermometers are, however, based on the analysis of the mixture of the COC and SFS, and thus may be significantly affected by the above-mentioned heterogeneity. In this study, I have evaluated the heterogeneity-induced effects on the conventional paleothermometers of Porites skeletons using published $\mathrm{Sr} / \mathrm{Ca}, \delta^{18} \mathrm{O}$ and volume-fraction data of the COC and SFS and published observations of seasonal variability of bulk skeletal density. Results indicate that the effects may yield significant or serious errors in paleotemperature reconstruction.

\section{Introduction}

$\mathrm{Sr} / \mathrm{Ca}$ and $\delta^{18} \mathrm{O}$ of shallow-water coral skeletons are important proxies for past sea-surface temperature (McConnaughey 1989; Beck et al. 1992). On the other hand, application of secondary ion microprobe mass spectrometry (SIMS) to the skeletons has revealed microscale heterogeneity in both $\mathrm{Sr} / \mathrm{Ca}$ and $\delta^{18} \mathrm{O}$, which is not due to temperature effects but by biological effects. The microscale heterogeneity is that the $\mathrm{Sr} / \mathrm{Ca}$ and $\delta^{18} \mathrm{O}$ values differ significantly between two fundamental microfeatures of the skeleton: the center of calcification (COC: generally less than tens of $\mu \mathrm{m}$ in diameter) and surrounding fibrous skeleton (SFS) (Allison 1996; Cohen et al. 2001; Allison and Finch 2004; Allison et al. 2005; Meibom et al. 2006; JuilletLeclerc et al. 2009). Cohen et al. (2001) suggest that the COC and SFS grow at night and during the day, respectively. The COC consists of submicron-sized granular crystals intermingled with significant amount of organic matter; the SFS is composed of bundles of larger acicular aragonite crystals and constitutes the bulk of the skeleton (Cohen et al. 2001; Meibom et al. 2007; Holcomb et al. 2009), indicating that highly irregular crystal growth occurs at the COC. It has been suggested that the $\mathrm{COC}$ has much larger amounts of crystal defects and crystal-organic interfaces into which various minor and trace elements are incorporated or adsorbed (Mitsuguchi et al. 2010; Mitsuguchi and Kawakami 2012) and that the COC may be more prone to diagenetic alteration than the SFS (Allison et al. 2005). Thus, avoiding the COC or analyzing the SFS only, would probably be favourable for paleotemperature reconstruction,

Keywords. Coral; $\mathrm{Sr} / \mathrm{Ca} ; \delta^{18} \mathrm{O}$; center of calcification; paleotemperature; microscale heterogeneity. 
although doing this for a long coral core (e.g., 2-3 $\mathrm{m}$ in length) using the present SIMS technique would be an extremely time-consuming work.

In conventional methods of coral-skeleton-based paleotemperature reconstruction, the skeleton is sampled along its growth direction at intervals of $\geq 0.25 \mathrm{~mm}$ (mostly $0.5-1.0 \mathrm{~mm}$ ) using a tool such as a microdrill or needle, and the obtained samples are subjected to elemental/isotopic analyses. In this case, each sample is a mixture of the COC and SFS, which may yield significant differences in paleotemperature reconstruction compared with the case of analyzing the SFS only. Furthermore, the amount ratio of the COC to the SFS is seasonally variable within individual coral colonies, which is described as follows: the thickness of skeletal structures, which corresponds to the total thickness of the COC plus SFS, is generally seasonally variable (this process produces skeletal density banding), while the thickness of the COC is likely to be almost constant or less variable than the structural thickness. This idea was proposed by Mitsuguchi and Kawakami (2012). In addition, the amount ratio of the COC to the SFS may vary between coral colonies, if they are different species or if they are the same species but growing in quite different environments. These possible variations in the $\mathrm{COC} / \mathrm{SFS}$ ratio may generate significant errors in the conventional paleotemperature reconstruction.

In this paper, I evaluate the effects of the COCSFS mixing and seasonal COC/SFS variability on the conventional $\mathrm{Sr} / \mathrm{Ca}$ and $\delta^{18} \mathrm{O}$ paleothermometers of Porites coral skeletons by calculation using published data and observations. The Porites skeletons are most widely used for coral-based paleostudies. Main structural elements of the skeletons vary from $\sim 50$ to $\sim 300 \mu \mathrm{m}$ in thickness; this range covers not only within-colony seasonal variation but also inter-colony and inter-species variations.
It has been reported that the COC of the skeletons is generally $5-20 \mu \mathrm{m}$ in diameter (Allison 1996; Allison et al. 2005, 2007).

\section{Calculation and data}

All variables used in my calculation are listed and described in table 1 . The effects of the COC-SFS mixing on the $\mathrm{Sr} / \mathrm{Ca}$ and $\delta^{18} \mathrm{O}$ values are expressed by the following equations.

$$
\begin{aligned}
(\mathrm{Sr} / \mathrm{Ca})_{\mathrm{MIX}} & =\frac{V_{\mathrm{SFS}}(\mathrm{Sr} / \mathrm{Ca})_{\mathrm{SFS}}+\phi V_{\mathrm{COC}}(\mathrm{Sr} / \mathrm{Ca})_{\mathrm{COC}}}{V_{\mathrm{SFS}}+\phi V_{\mathrm{COC}}} \\
\left(\delta^{18} \mathrm{O}\right)_{\mathrm{MIX}} & =\frac{V_{\mathrm{SFS}}\left(\delta^{18} \mathrm{O}\right)_{\mathrm{SFS}}+\phi V_{\mathrm{COC}}\left(\delta^{18} \mathrm{O}\right)_{\mathrm{COC}}}{V_{\mathrm{SFS}}+\phi V_{\mathrm{COC}}} .
\end{aligned}
$$

It has been observed that the COC occupies 3-4 vol.\% and 19 vol.\% of modern and fossil Porites skeletons, respectively (Allison 1996; Allison et al. 2005). Thus, I adopt the following conditions: $\left(V_{\mathrm{COC}}, V_{\mathrm{SFS}}\right)=(3,97),(5,95),(10,90)$, $(15,85)$ and $(20,80)$. Meibom et al. (2007) applied NanoSIMS analyses to a modern Porites skeleton and observed that the ${ }^{40} \mathrm{Ca}^{+}$signal near the $\mathrm{COC}$ was $\sim 20 \%$ lower than that of the SFS and that the ${ }^{12} \mathrm{C}^{-}$signal near the COC was $\sim 50 \%$ higher than that of the SFS, suggesting lower (higher) concentration of calcium-carbonate (organic) material at the COC. Thus, I set $\phi=0.8$. Published measurements of $(\mathrm{Sr} / \mathrm{Ca})_{\mathrm{COC}},(\mathrm{Sr} / \mathrm{Ca})_{\mathrm{SFS}},\left(\delta^{18} \mathrm{O}\right)_{\mathrm{COC}}$ and $\left(\delta^{18} \mathrm{O}\right)_{\mathrm{SFS}}$ for shallow-water corals (Porites, Colpophyllia and Acropora) are listed in table 2. Unfortunately, there seems to be no published data for Porites $\left(\delta^{18} \mathrm{O}\right)_{\mathrm{COC}}$ and $\left(\delta^{18} \mathrm{O}\right)_{\mathrm{SFS}}$. Under these conditions, I calculate $(\mathrm{Sr} / \mathrm{Ca})_{\text {MIX }}$ and $\left(\delta^{18} \mathrm{O}\right)_{\text {MIX }}$. Applying the slope of the linear $\mathrm{Sr} / \mathrm{Ca}$-temperature

Table 1. List of variables used in this study.

\begin{tabular}{ll}
\hline Variable & \multicolumn{1}{c}{ Description } \\
\hline$V_{\mathrm{COC}}$ & Volume of the COC \\
$V_{\mathrm{SFS}}$ & Volume of the SFS \\
$\phi$ & Volume fraction of calcium-carbonate material in the COC \\
$(\mathrm{Sr} / \mathrm{Ca})_{\mathrm{COC}}$ & $\mathrm{Sr} / \mathrm{Ca}(\mathrm{mmol} / \mathrm{mol})$ of the COC \\
$(\mathrm{Sr} / \mathrm{Ca})_{\mathrm{SFS}}$ & $\mathrm{Sr} / \mathrm{Ca}(\mathrm{mmol} / \mathrm{mol})$ of the SFS \\
$(\mathrm{Sr} / \mathrm{Ca})_{\mathrm{MIX}}$ & $\mathrm{Sr} / \mathrm{Ca}(\mathrm{mmol} / \mathrm{mol})$ of the mixture of the COC and SFS \\
$\left(\delta^{18} \mathrm{O}\right)_{\mathrm{COC}}$ & $\delta^{18} \mathrm{O}_{\mathrm{VPDB}}(\%)$ of the COC \\
$\left(\delta^{18} \mathrm{O}\right)_{\mathrm{SFS}}$ & $\delta^{18} \mathrm{O}_{\mathrm{VPDB}}(\%)$ of the SFS \\
$\left(\delta^{18} \mathrm{O}\right)_{\mathrm{MIX}}$ & $\delta^{18} \mathrm{O} \mathrm{VPDB}(\%)$ of the mixture of the COC and SFS \\
$\Delta t[\mathrm{Sr} / \mathrm{Ca}]$ & $\mathrm{COC}-\mathrm{SFS}$ mixing effect on conventional Sr/Ca paleothermometer $\left({ }^{\circ} \mathrm{C}\right)$ \\
$\Delta t\left[\delta^{18} \mathrm{O}\right]$ & $\mathrm{COC}-\mathrm{SFS}$ mixing effect on conventional $\delta^{18} \mathrm{O}$ paleothermometer $\left({ }^{\circ} \mathrm{C}\right)$ \\
$\Delta T[\mathrm{Sr} / \mathrm{Ca}]$ & Effect of seasonal COC $/ \mathrm{SFS}$ variability on conventional Sr/Ca paleothermometer $\left({ }^{\circ} \mathrm{C}\right)$ \\
$\Delta T\left[\delta^{18} \mathrm{O}\right]$ & Effect of seasonal COC/SFS variability on conventional $\delta^{18} \mathrm{O}$ paleothermometer $\left({ }^{\circ} \mathrm{C}\right)$ \\
\hline
\end{tabular}


Table 2. Published measurements of $S r / C a$ and $\delta^{18} O$ in the center of calcification (COC) and surrounding fibrous skeleton (SFS) of shallow-water corals.

\begin{tabular}{|c|c|c|c|c|c|}
\hline Reference & $(\mathrm{Sr} / \mathrm{Ca})_{\mathrm{COC}^{\mathrm{a}}}$ & $(\mathrm{Sr} / \mathrm{Ca})_{\mathrm{SFS}}{ }^{\mathrm{a}}$ & $\left(\delta^{18} \mathrm{O}\right)_{\mathrm{COC}}^{\mathrm{b}}$ & $\left(\delta^{18} \mathrm{O}\right)_{\mathrm{SFS}}^{\mathrm{b}}$ & Sample \\
\hline Allison and Finch (2004) & 9.3 & 8.9 & - & - & Modern Porites \\
\hline Allison et al. (2005) & 9.18 & 8.85 & - & - & Modern Porites \\
\hline Allison et al. (2005) & 10.21 & 8.92 & - & - & Fossil Porites \\
\hline Meibom et al. (2006) & $10.1^{\mathrm{c}}$ & $9.0^{\mathrm{d}}$ & $-3.9^{\mathrm{e}}$ & $-2.0^{f}$ & Modern Colpophyllia \\
\hline Juillet-Leclerc et al. (2009) & - & - & -4.9 & -2.6 & Modern Acropora \\
\hline
\end{tabular}

${ }^{\mathrm{a}}$ In $\mathrm{mmol} / \mathrm{mol}$.

${ }^{\mathrm{b}}$ In $\% 0$ (VPDB).

${ }^{\mathrm{c}}$ Approx. mean of the data ranging from 9.8 to $10.4 \mathrm{mmol} / \mathrm{mol}$.

${ }^{\mathrm{d}}$ Approx. mean of the data ranging from 8.6 to $10.0 \mathrm{mmol} / \mathrm{mol}$.

${ }^{\mathrm{e}}$ Approx. mean of the data ranging from -5.2 to $-2.4 \%$.

${ }^{\mathrm{f}}$ Approx. mean of the data ranging from -2.6 to $-1.3 \%$.

relationship to the difference between $(\mathrm{Sr} / \mathrm{Ca})_{\mathrm{MIX}}$ and $(\mathrm{Sr} / \mathrm{Ca})_{\mathrm{SFS}}$ (i.e., $\left.(\mathrm{Sr} / \mathrm{Ca})_{\mathrm{MIX}}-(\mathrm{Sr} / \mathrm{Ca})_{\mathrm{SFS}}\right)$ allows me to evaluate the COC-SFS mixing effect on the $\mathrm{Sr} / \mathrm{Ca}$ paleothermometer. Similarly, the COC-SFS mixing effect on the $\delta^{18} \mathrm{O}$ paleothermometer can be evaluated. In this study, I use the $\mathrm{Sr} / \mathrm{Ca}$-temperature and $\delta^{18} \mathrm{O}$-temperature slopes of $-0.0607 \mathrm{mmol} / \mathrm{mol} /{ }^{\circ} \mathrm{C}$ and $-0.167 \%$ o $/{ }^{\circ} \mathrm{C}$, respectively, which are mean slopes for Porites skeletons (Corrège 2006; Gagan et al. 2012). As shown in table $2,(\mathrm{Sr} / \mathrm{Ca})_{\mathrm{COC}}$ is higher than $(\mathrm{Sr} / \mathrm{Ca})_{\mathrm{SFS}}$, and $\left(\delta^{18} \mathrm{O}\right)_{\mathrm{COC}}$ is lower than $\left(\delta^{18} \mathrm{O}\right)_{\mathrm{SFS}}$. Consequently, the COC-SFS mixing effects on the two paleothermometers are in opposite directions.

In order to evaluate the effects of seasonal COC/SFS variability on the two paleothermometers, I set the following conditions: (1) the sum of $V_{\mathrm{SFS}}$ and $V_{\mathrm{COC}}$ varies seasonally (in a sinusoidal form) with its maximum 1.8 times its minimum; (2) $V_{\mathrm{COC}}$ is constant; (3) $(\mathrm{Sr} / \mathrm{Ca})_{\mathrm{COC}},(\mathrm{Sr} / \mathrm{Ca})_{\mathrm{SFS}}$, $\left(\delta^{18} \mathrm{O}\right)_{\mathrm{COC}}$ and $\left(\delta^{18} \mathrm{O}\right)_{\mathrm{SFS}}$ are all constant (i.e., the values in table 2 are used). The first condition is based on the observation that, within individual Porites colonies, the highest bulk skeletal density is generally not more than 1.8 times the lowest bulk skeletal density (Buddemeier 1974; Lough and Barnes 1992). I use the following $V_{\mathrm{COC}}$ values and $V_{\mathrm{SFS}}$ ranges: $\left(V_{\mathrm{COC}}, V_{\mathrm{SFS}}\right)=\left(3,68.5_{-}^{-}\right.$ $125.5),(5,66.5-123.5),(10,61.5-118.5),(15,56.5-$ $113.5)$ and $(20,51.5-108.5)$. For each $\left(V_{\mathrm{COC}}, V_{\mathrm{SFS}}\right)$ pair, I calculate variabilities of $(\mathrm{Sr} / \mathrm{Ca})_{\mathrm{MIX}}$ and $\left(\delta^{18} \mathrm{O}\right)_{\mathrm{MIX}}$ and convert the variabilities into temperatures using the $\mathrm{Sr} / \mathrm{Ca}$-temperature and $\delta^{18} \mathrm{O}$ temperature slopes. Thus, the effects of seasonal COC/SFS variability on the two paleothermometers are evaluated; a schematic illustration of the effects is presented in figure 1 . It should be noted that I evaluate the 'maximum effects' of seasonal COC/SFS variability since I assume the maximum seasonality of bulk skeletal density.
SFS : surrounding fibrous skeleton

COC : center of calcification, generally $5-20 \mu \mathrm{m}$ in diameter for Porites skeleton

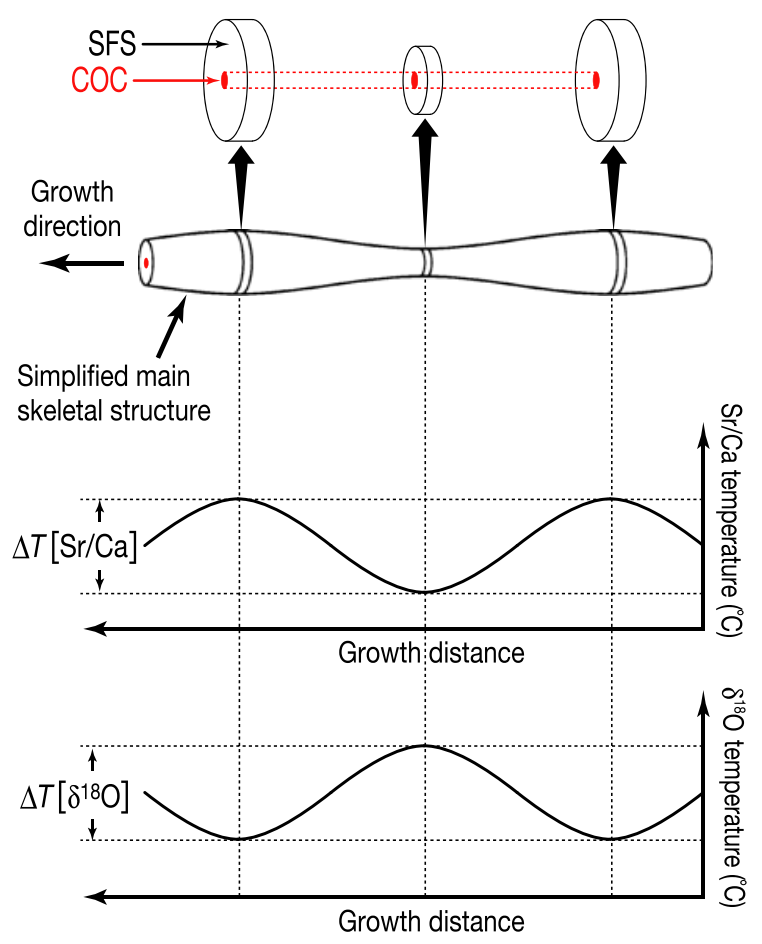

Figure 1. Schematic illustration of the effects of seasonal COC/SFS variability on conventional $\mathrm{Sr} / \mathrm{Ca}$ and $\delta^{18} \mathrm{O}$ paleothermometers.

\section{Results and discussion}

Calculation results for the COC-SFS mixing effects $\left(\Delta t[\mathrm{Sr} / \mathrm{Ca}]\right.$ and $\left.\Delta t\left[\delta^{18} \mathrm{O}\right]\right)$ are shown in table 3 and those for the effects of seasonal COC/SFS variability $\left(\Delta T[\mathrm{Sr} / \mathrm{Ca}]\right.$ and $\left.\Delta T\left[\delta^{18} \mathrm{O}\right]\right)$ are shown in table 4. Results based on the Allison et al.'s (2005) and Meibom et al.'s (2006) modern Sr/Ca data are not shown in the tables, because they 
Table 3. Calculation results for the COC-SFS mixing effects on conventional Sr/Ca and $\delta^{18}$ O paleothermometers.

\begin{tabular}{lccccccc}
\hline $\begin{array}{l}\text { Condition } \\
\text { no. }\end{array}$ & $V_{\mathrm{COC}}$ & $V_{\mathrm{SFS}}$ & $\phi$ & $\begin{array}{c}\Delta t[\mathrm{Sr} / \mathrm{Ca}] \\
\left({ }^{\circ} \mathrm{C}\right)^{\mathrm{a}}\end{array}$ & $\begin{array}{c}\Delta t[\mathrm{Sr} / \mathrm{Ca}] \\
\left({ }^{\circ} \mathrm{C}\right)^{\mathrm{b}}\end{array}$ & $\begin{array}{r}\Delta t\left[\delta^{18} \mathrm{O}\right] \\
\left({ }^{\circ} \mathrm{C}\right)^{\mathrm{c}}\end{array}$ & $\begin{array}{c}\Delta t\left[\delta^{18} \mathrm{O}\right] \\
\left({ }^{\circ} \mathrm{C}\right)^{\mathrm{d}}\end{array}$ \\
\hline 1 & 3 & 97 & 0.8 & -0.16 & -0.51 & 0.27 & 0.33 \\
2 & 5 & 95 & 0.8 & -0.27 & -0.86 & 0.46 & 0.56 \\
3 & 10 & 90 & 0.8 & -0.54 & -1.73 & 0.93 & 1.12 \\
4 & 15 & 85 & 0.8 & -0.82 & -2.63 & 1.41 & 1.70 \\
5 & 20 & 80 & 0.8 & -1.10 & -3.54 & 1.90 & 2.30 \\
\hline
\end{tabular}

${ }^{a}$ Calculation is based on the Allison and Finch's (2004) modern Porites Sr/Ca data (see table 2).

${ }^{\mathrm{b}}$ Calculation is based on the Allison et al.'s (2005) fossil Porites Sr/Ca data (see table 2).

${ }^{\mathrm{c}}$ Calculation is based on the Meibom et al.'s (2006) modern Colpophyllia $\delta^{18} \mathrm{O}$ data (see table 2).

${ }^{\mathrm{d}}$ Calculation is based on the Juillet-Leclerc et al.'s (2009) modern Acropora $\delta^{18} \mathrm{O}$ data (see table 2).

Table 4. Calculation results for the effects of seasonal COC/SFS variability on conventional $\mathrm{Sr} / \mathrm{Ca}$ and $\delta^{18} \mathrm{O}$ paleothermometers.

\begin{tabular}{|c|c|c|c|c|c|c|c|}
\hline $\begin{array}{l}\text { Condition } \\
\text { no. }\end{array}$ & $V_{\mathrm{COC}}$ & $V_{\mathrm{SFS}}$ & $\phi$ & $\begin{array}{c}\Delta T[\mathrm{Sr} / \mathrm{Ca}] \\
\left({ }^{\circ} \mathrm{C}\right)^{\mathrm{a}}\end{array}$ & $\begin{array}{c}\Delta T[\mathrm{Sr} / \mathrm{Ca}] \\
\left({ }^{\circ} \mathrm{C}\right)^{\mathrm{b}}\end{array}$ & $\begin{array}{c}\Delta T\left[\delta^{18} \mathrm{O}\right] \\
\quad\left({ }^{\circ} \mathrm{C}\right)^{\mathrm{c}}\end{array}$ & $\begin{array}{c}\Delta T\left[\delta^{18} \mathrm{O}\right] \\
\quad\left({ }^{\circ} \mathrm{C}\right)^{\mathrm{d}}\end{array}$ \\
\hline 1 & 3 & $68.5-125.5$ & 0.8 & 0.10 & 0.32 & 0.17 & 0.21 \\
\hline 2 & 5 & $66.5-123.5$ & 0.8 & 0.17 & 0.54 & 0.29 & 0.35 \\
\hline 3 & 10 & $61.5-118.5$ & 0.8 & 0.34 & 1.10 & 0.59 & 0.71 \\
\hline 4 & 15 & $56.5-113.5$ & 0.8 & 0.52 & 1.69 & 0.91 & 1.10 \\
\hline 5 & 20 & $51.5-108.5$ & 0.8 & 0.72 & 2.31 & 1.23 & 1.49 \\
\hline
\end{tabular}

${ }^{a}$ Calculation is based on the Allison and Finch's (2004) modern Porites Sr/Ca data (see table 2).

${ }^{\mathrm{b}}$ Calculation is based on the Allison et al.'s (2005) fossil Porites Sr/Ca data (see table 2).

${ }^{\mathrm{c}}$ Calculation is based on the Meibom et al.'s (2006) modern Colpophyllia $\delta^{18} \mathrm{O}$ data (see table 2).

${ }^{\mathrm{d}}$ Calculation is based on the Juillet-Leclerc et al.'s (2009) modern Acropora $\delta^{18} \mathrm{O}$ data (see table 2).

are similar to the shown results based on the Allison and Finch's (2004) modern Sr/Ca data and Allison et al.'s (2005) fossil $\mathrm{Sr} / \mathrm{Ca}$ data, respectively. In the case of the Allison and Finch's (2004) data (i.e., $(\mathrm{Sr} / \mathrm{Ca})_{\mathrm{COC}}-(\mathrm{Sr} / \mathrm{Ca})_{\mathrm{SFS}}=$ $0.4 \mathrm{mmol} / \mathrm{mol}),|\Delta t[\mathrm{Sr} / \mathrm{Ca}]|$ varies from $0.16^{\circ} \mathrm{C}$ $\left(V_{\mathrm{COC}}=3 \mathrm{vol} . \%\right)$ to $1.10^{\circ} \mathrm{C}\left(V_{\mathrm{COC}}=20 \mathrm{vol} . \%\right)$; $|\Delta T[\mathrm{Sr} / \mathrm{Ca}]|$ ranges from $0.10^{\circ} \mathrm{C}\left(V_{\mathrm{COC}}=3 \mathrm{vol} . \%\right)$ to $0.72^{\circ} \mathrm{C}\left(V_{\mathrm{COC}}=20 \mathrm{vol} . \%\right)$, indicating that, when $V_{\mathrm{COC}} \geq \sim 15$ vol.\%, both of the effects cause considerable errors in paleotemperature reconstruction. In the case of Allison et al.'s (2005) fossil data (i.e., $\left.(\mathrm{Sr} / \mathrm{Ca})_{\mathrm{COC}}-(\mathrm{Sr} / \mathrm{Ca})_{\mathrm{SFS}}=1.29 \mathrm{mmol} / \mathrm{mol}\right)$, the above-calculated $|\Delta t[\mathrm{Sr} / \mathrm{Ca}]|$ and $|\Delta T[\mathrm{Sr} / \mathrm{Ca}]|$ values are approximately tripled: $|\Delta t[\mathrm{Sr} / \mathrm{Ca}]|=$ $0.51^{\circ}-3.54^{\circ} \mathrm{C}$ and $|\Delta T[\mathrm{Sr} / \mathrm{Ca}]|=0.32^{\circ}-2.31^{\circ} \mathrm{C}$ for $V_{\mathrm{COC}}=3-20$ vol.\%, mostly indicating significant or serious errors in paleotemperature reconstruction. Allison et al. (2005) did similar calculation for $\Delta t[\mathrm{Sr} / \mathrm{Ca}]$, using their estimation of $V_{\mathrm{COC}}$ for a modern and a fossil Porites skeleton (4 and 19 vol.\%, respectively) and measurements of $(\mathrm{Sr} / \mathrm{Ca})_{\mathrm{COC}}$ and $(\mathrm{Sr} / \mathrm{Ca})_{\mathrm{SFS}}$ of the skeletons (shown in table 2). They suggest that the higher Sr enrichment at the $\mathrm{COC}$ and larger $V_{\mathrm{COC}}$ of the fossil skeleton are due to diagenetic alteration (i.e., replacement of the original COC by secondary aragonite cement). If this is the case, then $\phi \approx$ $1,|\Delta t[\mathrm{Sr} / \mathrm{Ca}]| \approx 0.64^{\circ}-4.25^{\circ} \mathrm{C}$, and $|\Delta T[\mathrm{Sr} / \mathrm{Ca}]|$ $\approx 0.40^{\circ}-2.64^{\circ} \mathrm{C}$ for $V_{\mathrm{COC}}=3-20$ vol. $\%$. On the other hand, Meibom et al. (2006) observed a similarly high enrichment of Sr at the COC of a modern Colpophyllia skeleton (see table 2); the COC of the skeleton is exceptionally large $(\sim 100 \mu \mathrm{m}$ in diameter) and thus $V_{\mathrm{COC}}$ is likely to be relatively large, suggesting larger $|\Delta t[\mathrm{Sr} / \mathrm{Ca}]|$ values for Colpophyllia. Cohen et al. (2001) observed, in a modern Porites coral, that $(\mathrm{Sr} / \mathrm{Ca})_{\mathrm{COC}}$ was $\sim 0$ $0.7 \mathrm{mmol} / \mathrm{mol}$ higher than $(\mathrm{Sr} / \mathrm{Ca})_{\mathrm{SFS}}$; the $\sim 0$ and $\sim 0.7 \mathrm{mmol} / \mathrm{mol}$ differences occur when the coral grows at the annual minimum and maximum seawater temperatures, respectively (data not shown in table 2$)$. The $(\mathrm{Sr} / \mathrm{Ca})_{\mathrm{COC}^{-}}-(\mathrm{Sr} / \mathrm{Ca})_{\mathrm{SFS}}$ difference of $\sim 0.7 \mathrm{mmol} / \mathrm{mol}$ is larger than the observation of Allison and Finch (2004) for a modern Porites coral (i.e., $0.4 \mathrm{mmol} / \mathrm{mol}$ ) and smaller than that of Allison et al. (2005) for a fossil Porites coral (i.e., $1.29 \mathrm{mmol} / \mathrm{mol}$ ) (see table 2).

If the Meibom et al.'s $(2006) \delta^{18} \mathrm{O}$ data is used, $\Delta t\left[\delta^{18} \mathrm{O}\right]$ varies from $0.27^{\circ} \mathrm{C}\left(V_{\mathrm{COC}}=3\right.$ vol. $\left.\%\right)$ to $1.90^{\circ} \mathrm{C}\left(V_{\mathrm{COC}}=20\right.$ vol. $\left.\%\right)$ and $\Delta T\left[\delta^{18} \mathrm{O}\right]$ ranges from $0.17^{\circ} \mathrm{C}\left(V_{\mathrm{COC}}=3 \mathrm{vol} . \%\right)$ to $1.23^{\circ} \mathrm{C}\left(V_{\mathrm{COC}}=\right.$ 
$20 \mathrm{vol} . \%)$; in the case of the Juillet-Leclerc et al.'s (2009) data, $\Delta t\left[\delta^{18} \mathrm{O}\right]$ varies from $0.33^{\circ} \mathrm{C}\left(V_{\mathrm{COC}}=\right.$ 3 vol. $\%)$ to $2.30^{\circ} \mathrm{C}\left(V_{\mathrm{COC}}=20\right.$ vol. $\left.\%\right)$ and $\Delta T\left[\delta^{18} \mathrm{O}\right]$ ranges from $0.21^{\circ} \mathrm{C}\left(V_{\mathrm{COC}}=3\right.$ vol. $\left.\%\right)$ to $1.49^{\circ} \mathrm{C}\left(V_{\mathrm{COC}}=20 \mathrm{vol} . \%\right)$, indicating significant or serious errors in paleotemperature reconstruction when $V_{\mathrm{COC}} \geq 5$ or 10 vol.\%. The Meibom et al.'s (2006) and Juillet-Leclerc et al.'s (2009) $\delta^{18} \mathrm{O}$ data are derived from different genera: Colpophyllia and Acropora, respectively. Despite the difference in genus, the two datasets are similar for the difference between $\left(\delta^{18} \mathrm{O}\right)_{\mathrm{COC}}$ and $\left(\delta^{18} \mathrm{O}\right)_{\mathrm{SFS}}$, i.e., the former indicates that $\left(\delta^{18} \mathrm{O}\right)_{\mathrm{COC}}$ is $1.9 \%$ lower than $\left(\delta^{18} \mathrm{O}\right)_{\mathrm{SFS}}$, and the latter shows that $\left(\delta^{18} \mathrm{O}\right)_{\mathrm{COC}}$ is $2.3 \%$ lower than $\left(\delta^{18} \mathrm{O}\right)_{\mathrm{SFS}}$ (see table 2). Thus, $\mathrm{I}$ infer that the $\left(\delta^{18} \mathrm{O}\right)_{\mathrm{COC}^{-}}\left(\delta^{18} \mathrm{O}\right)_{\mathrm{SFS}}$ difference does not vary significantly between symbiotic coral genera, and that the two datasets are applicable to Porites.

The COC-SFS mixing effect and the effect of seasonal COC/SFS variability would generally combine to complicate the problem. The problem is further complicated by the fact that the formation of annual density bands in Porites skeletons greatly varies depending on individual colonies; for example, (1) some colonies form a high-density band in a warm season and others in a cool season even in the same region and (2) some colonies form distinct couplets of high- and low-density annual bands and others do not. This complication may be a cause of the fact that there are significant differences between conventional Sr/Ca-temperature (or $\delta^{18} \mathrm{O}$-temperature) relationships for Porites skeletons (Corrège 2006; Gagan et al. 2012). In addition, the COC-SFS mixing effects on the two paleothermometers are in opposite directions (see table 3), and the effects of seasonal COC/SFS variability on the two are also in opposite directions (see figure 1), which may greatly perturb the paleosalinity reconstruction by the combination of conventional $\mathrm{Sr} / \mathrm{Ca}$ and $\delta^{18} \mathrm{O}$ analyses (McCulloch et al. 1994; Gagan et al. 1998).

So far, only small amounts of data have been published for $V_{\mathrm{COC}},(\mathrm{Sr} / \mathrm{Ca})_{\mathrm{COC}^{-}}(\mathrm{Sr} / \mathrm{Ca})_{\mathrm{SFS}}$ difference, and $\left(\delta^{18} \mathrm{O}\right)_{\mathrm{COC}^{-}}\left(\delta^{18} \mathrm{O}\right)_{\mathrm{SFS}}$ difference. Collection of these data will enable more accurate evaluation of the effects of the COC-SFS mixing and seasonal COC/SFS variability, and will probably lead to methodological improvements or changes for more accurate paleotemperature and paleosalinity reconstructions.

\section{Acknowledgements}

The author is grateful to two anonymous reviewers and Associate Editor, Dr. Anindya Sarkar for their comments and suggestions on the manuscript.

\section{References}

Allison N 1996 Geochemical anomalies in coral skeletons and their possible implications for palaeoenvironmental analyses; Marine Chem. 55 367-379.

Allison N and Finch A A 2004 High-resolution Sr/Ca records in modern Porites lobata corals: Effects of skeletal extension rate and architecture; Geochem. Geophys. Geosyst. 5 Q05001, doi: 10.1029/2004GC000696.

Allison N, Finch A A, Tudhope A W, Newville M, Sutton S R and Ellam R M 2005 Reconstruction of deglacial sea surface temperatures in the tropical Pacific from selective analysis of a fossil coral; Geophys. Res. Lett. 32 L17609, doi: 10.1029/2005GL023183.

Allison N, Finch A A, Webster J M and Clague D A 2007 Palaeoenvironmental records from fossil corals: The effects of submarine diagenesis on temperature and climate estimates; Geochim. Cosmochim. Acta 71 4693-4703.

Beck J W, Edwards R L, Ito E, Taylor F W, Récy J, Rougerie F, Joannot P and Henin C 1992 Sea-surface temperature from coral skeletal strontium/calcium ratios; Science 257 644-647.

Buddemeier R W 1974 Environmental controls over annual and lunar monthly cycles in hermatypic coral calcification; Proc. 2nd Int. Coral Reef Symp. 2 259-267.

Cohen A L, Layne G D, Hart S R and Lobel P S 2001 Kinetic control of skeletal $\mathrm{Sr} / \mathrm{Ca}$ in a symbiotic coral: Implications for the paleotemperature proxy; Paleoceanography $1620-26$.

Corrège T 2006 Sea surface temperature and salinity reconstruction from coral geochemical tracers; Palaeogeogr. Palaeoclimatol. Palaeoecol. 232 408-428.

Gagan M K, Ayliffe L K, Hopley D, Cali J A, Mortimer G E, Chappell J, McCulloch M T and Head M J 1998 Temperature and surface-ocean water balance of the mid-Holocene tropical western Pacific; Science $\mathbf{2 7 9}$ 1014-1018.

Gagan M K, Dunbar G B and Suzuki A 2012 The effect of skeletal mass accumulation in Porites on coral Sr/Ca and $\delta^{18} \mathrm{O}$ paleothermometry; Paleoceanography 27 PA1203, doi: 10.1029/2011PA002215.

Holcomb M, Cohen A L, Gabitov R I and Hutter J L 2009 Compositional and morphological features of aragonite precipitated experimentally from seawater and biogenically by corals; Geochim. Cosmochim. Acta $\mathbf{7 3}$ 4166-4179.

Juillet-Leclerc A, Reynaud S, Rollion-Bard C, Cuif J P, Dauphin Y, Blamart D, Ferrier-Pagès C and Allemand D 2009 Oxygen isotopic signature of the skeletal microstructures in cultured corals: Identification of vital effects; Geochim. Cosmochim. Acta 73 5320-5332.

Lough J M and Barnes D J 1992 Comparisons of skeletal density variations in Porites from the central Great Barrier Reef; J. Exp. Mar. Biol. Ecol. 155 $1-25$.

McConnaughey $\mathrm{T} 1989{ }^{13} \mathrm{C}$ and ${ }^{18} \mathrm{O}$ isotopic disequilibrium in biological carbonates: I. Patterns; Geochim. Cosmochim. Acta 53 151-162.

McCulloch M T, Gagan M K, Mortimer G E, Chivas A R and Isdale P J 1994 A high-resolution Sr/Ca and $\delta^{18} \mathrm{O}$ coral record from the Great Barrier Reef, Australia, and the 1982-1983 El Niño; Geochim. Cosmochim. Acta 58 2747-2754.

Meibom A, Yurimoto H, Cuif J P, Domart-Coulon I, Houlbreque F, Constantz B, Dauphin Y, Tambutté E, Tambutté S, Allemand D, Wooden J and Dunbar R 2006 Vital effects in coral skeletal composition display strict 
three-dimensional control; Geophys. Res. Lett. 33 L11608, doi: 10.1029/2006GL025968.

Meibom A, Mostefaoui S, Cuif J P, Dauphin Y, Houlbreque F, Dunbar R and Constantz B 2007 Biological forcing controls the chemistry of reef-building coral skeleton; Geophys. Res. Lett. 34 L02601, doi: 10.1029/2006GL028657.
Mitsuguchi T, Uchida T and Matsumoto E $2010 \mathrm{Na} / \mathrm{Ca}$ variability in coral skeletons; Geochem. J. 44 261-273.

Mitsuguchi T and Kawakami T 2012 Potassium and other minor elements in Porites corals: Implications for skeletal geochemistry and paleoenvironmental reconstruction; Coral Reefs 31 671-681.

MS received 3 December 2012; revised 17 March 2013; accepted 29 April 2013 